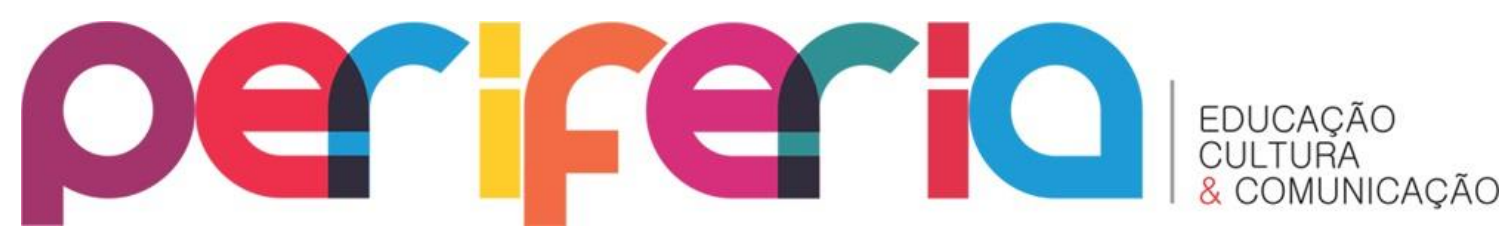

\title{
RIBEIRÃO DAS TREVAS? O SKATE DANDO UM OLLIE NAS NARRATIVAS DOMINANTES SOBRE RIBEIRÃO DAS NEVES / MG
}

\author{
Rafaela Goltara Souza ${ }^{1}$
}

\section{RESUMO}

Ribeirão das Neves-MG é uma cidade mineira que é constantemente notícia por causa das seis penitenciárias que abriga, do lixão sem tratamento adequado e pelo trocadilho publicado no Diário Oficial do Estado e no site do Tribunal de Justiça /MG citando-a pelo nome de Ribeirão das Trevas. Essa descrição pejorativa oficializada no município se impõe como uma barreira aos moradores da cidade, que sofrem com a estigmatização e exclusão social que essa narrativa acarreta. Porém, um grupo de jovens negros e skatistas entram em conflito com essa história única apresentando uma nova narrativa sobre a cidade, privilegiando a vida, a amizade e as sociabilidades. Este artigo é um desdobramento da dissertação de mestrado que se intitula "Ribeirão das Trevas: o skate dando um ollie nas narrativas dominantes sobre a cidade de Ribeirão das Neves - MG", desenvolvida com o apoio da CAPES no Programa de Pós-graduação em Educação, Cultura e Comunicação em Periferias Urbanas da Faculdade de Educação da Baixada Fluminense (FEBF/ UERJ). 0 artigo traz um relato de experiência sobre os caminhos percorridos desde a aprovação do projeto de pesquisa até a construção metodológica da etnografia, sendo a fotografia um recurso fundamental para a descoberta do campo e da relação tecida entre a etnógrafa e o grupo de skatistas Just Crew Skateboard, que aqui é compartilhada com o objetivo de contribuir com as reflexões sobre as possibilidades da imagem como simpatia, e da etnografia e antropologia visual como metodologias de pesquisa em periferias urbanas.

Palavras-chave: skatistas, Ribeirão das Neves, cidades, etnografia, periferias

\footnotetext{
1 Jornalista profissional e Mestranda em Educação, Cultura e Comunicação em Periferias Urbanas pela UERJ. Atua profissionalmente em revisão de conteúdos acadêmicos, produção e revisão de conteúdo com inteligência SEO e oferece consultoria em comunicação para movimentos sociais e oficinas para jovens em escolas públicas. ORCID iD: https://orcid.org/0000-0002-3019-1819. E-mail: rafaelagoltara@gmail.com.
}

Periferia, v. 12, n. 3, p. 322-346, set./dez. 2020 


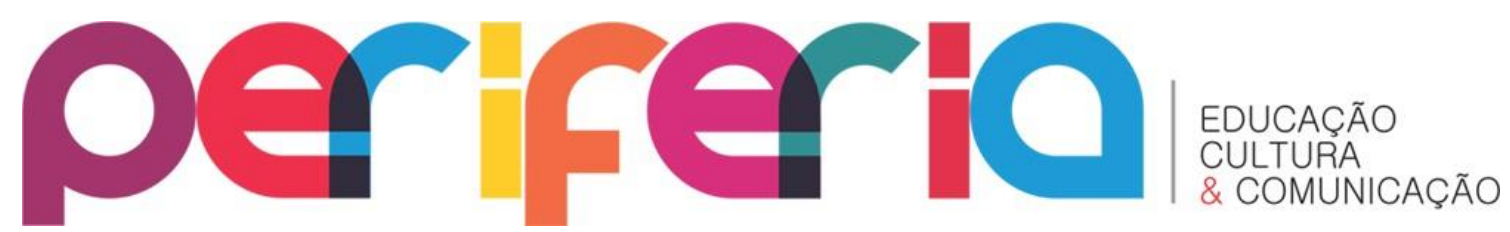

ISSN:1984-9540

DOI: $10.12957 /$ periferia.2020.49114

RIBEIRÃO DAS TREVAS? THE SKATE GIVING AN OLLIE IN THE DOMINANT NARRATIVES ABOUT RIBEIRÃO DAS NEVES / MG

\begin{abstract}
Ribeirão das Neves-MG is a mining town that is constantly in the news because of the six prisons it houses, the dump without proper treatment and the pun published in the Official Gazette of the State and on the website of the Court of Justice / MG citing it by the name of Ribeirão das Trevas. This official pejorative description in the municipality imposes itself as a barrier to city dwellers, who suffer from the stigmatization and social exclusion that this narrative entails. However, a group of young blacks and skaters come into conflict with this unique story, presenting a new narrative about the city, privileging life, friendship and sociability. This article is an offshoot of the master's thesis entitled "Ribeirão das Trevas: skateboarding an ollie in the dominant narratives about the city of Ribeirão das Neves - MG", developed with the support of CAPES in the Graduate Program in Education , Culture and Communication in Urban Peripheries of the Faculty of Education of Baixada Fluminense (FEBF / UERJ). The article brings an experience report on the paths taken from the approval of the research project to the methodological construction of ethnography, photography being a fundamental resource for discovering the field and the relationship woven between the ethnographer and the group of skaters Just Crew Skateboard, which is shared here in order to contribute to the reflections on the possibilities of image as sympathy, and of ethnography and visual anthropology as research methodologies in urban peripheries.
\end{abstract}

Keyword: skaters, Ribeirão das Neves, cities, ethnography, peripheries

\title{
RIBEIRÃO DAS TREVAS? RIBEIRÃO DAS TREVAS? EL SKATE DANDO UN OLLIE EN LAS NARRATIVAS DOMINANTES SOBRE RIBEIRÃO DAS NEVES / MG
}

\section{RESUMEN}

Ribeirão das Neves-MG es un pueblo minero que está constantemente en las noticias debido a las seis cárceles que alberga, el vertedero sin el tratamiento adecuado y el juego de palabras publicado en el Boletín Oficial del Estado y en el sitio web del Tribunal de Justicia / MG que lo cita con el nombre de Ribeirão das Trevas. Esta descripción peyorativa oficial en el municipio se impone como una barrera para los habitantes de la ciudad, que sufren la estigmatización y la exclusión social que conlleva esta narración. Sin embargo, un grupo de jóvenes negros y patinadores entran en conflicto con esta historia única, presentando una nueva narrativa sobre la ciudad, privilegiando la vida, la amistad y la sociabilidad. Este artículo es una rama de la tesis de maestría titulada "Ribeirão das Trevas: andar en monopatín con un

Periferia, v. 12, n. 3, p. 322-346, set./dez. 2020 


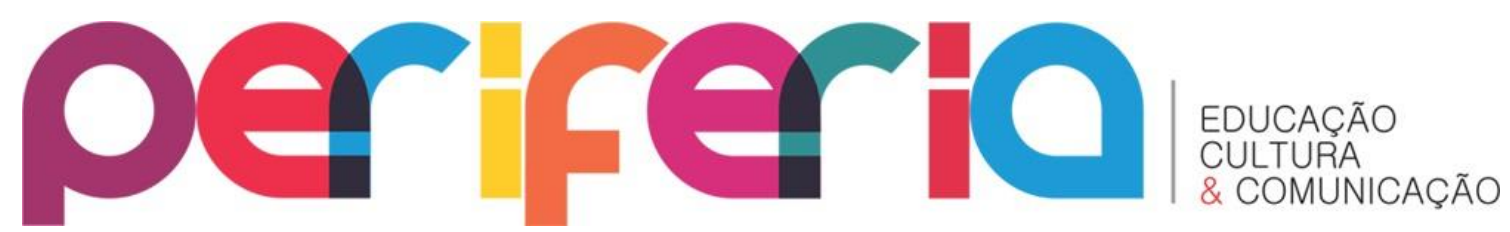

ISSN:1984-9540

DOI: $10.12957 /$ periferia.2020.49114 ollie en las narrativas dominantes sobre la ciudad de Ribeirão das Neves - MG", desarrollado con el apoyo de CAPES en el Programa de Posgrado en Educación , Cultura y Comunicación en Periferia Urbana de la Facultad de Educación de Baixada Fluminense (FEBF / UERJ). El artículo trae un informe de experiencia sobre los caminos tomados desde la aprobación del proyecto de investigación hasta la construcción metodológica de la etnografía, siendo la fotografía un recurso fundamental para descubrir el campo y la relación entre el etnógrafo y el grupo de patinadores Just Crew Skateboard, que se comparte aquí para contribuir a las reflexiones sobre las posibilidades de la imagen como simpatía, y de la etnografía y la antropología visual como metodologías de investigación en las periferias urbanas.

Palabra-clave: skaters, Ribeirão das Neves, ciudades, etnografía, periferias

\section{INTRODUÇÃO}

Ribeirão das Neves-MG é uma cidade mineira que é constantemente notícia por causa das seis penitenciárias que abriga, do lixão sem tratamento adequado e pelo trocadilho publicado no Diário Oficial do Estado e no site do Tribunal de Justiça /MG citando-a pelo nome de Ribeirão das Trevas. Essa descrição pejorativa oficializada no município se impõe como uma barreira aos moradores da cidade, que sofrem com a estigmatização e exclusão social que essa narrativa acarreta. Porém, um grupo de jovens negros e skatistas entram em conflito com essa história única apresentando uma nova narrativa sobre a cidade, privilegiando a vida, a amizade e as sociabilidades. A primeira manobra que um skatista aprende é o ollie: pulo que tira o skate do chão e é base para os saltos sobre obstáculos, como ollie sobre escada, ollie sobre barra, etc. 0 grupo conhecido como Just Crew Skateboard ocupou o coreto de uma pracinha e o transformou em pista, dando um ollie na falta de infraestrutura local e nos estigmas impostos aos jovens negros de periferias. Há 20 anos eles capacitam uns aos outros na prática esportiva, se apoiam nos estudos e relações familiares, e constroem seus próprios skates e obstáculos, tornando-se educadores uns dos outros e ensinando um novo jeito de olhar para Ribeirão das Neves e para eles próprios.

Periferia, v. 12, n. 3, p. 322-346, set./dez. 2020 


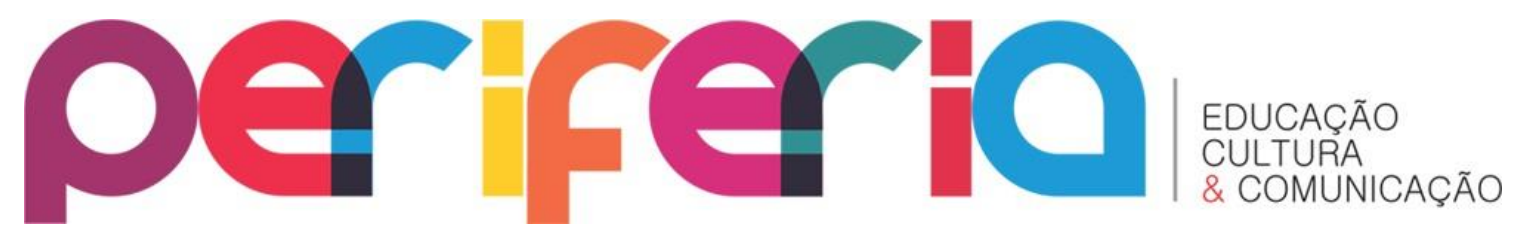

ISSN:1984-9540

DOI: $10.12957 /$ periferia. 2020.49114

Este artigo é um desdobramento da dissertação de mestrado que se intitula "Ribeirão das Trevas: o skate dando um ollie nas narrativas dominantes sobre a cidade de Ribeirão das Neves - MG", desenvolvida com o apoio da CAPES no Programa de Pós-graduação em Educação, Cultura e Comunicação em Periferias Urbanas da Faculdade de Educação da Baixada Fluminense (FEBF/ UERJ). $O$ artigo traz um relato de experiência sobre os caminhos percorridos desde a aprovação do projeto de pesquisa até a construção metodológica da etnografia, sendo a fotografia um recurso fundamental para a descoberta do campo e da relação tecida entre esta etnógrafa e o grupo de skatistas Just Crew Skateboard, que aqui é compartilhada com o objetivo de contribuir com as reflexões sobre as possibilidades da antropologia visual e da etnografia como metodologias de pesquisa em periferias urbanas.

\section{CONHECENDO O TERRITÓRIO: AS TREVAS DO RIBEIRÃO}

Em 2013, uma reportagem foi amplamente divulgada em vários canais de comunicação sobre uma publicação do Diário Oficial do Município (DOM) de Minas Gerais em que constava o nome da cidade mineira Ribeirão das Neves grafado como "Ribeirão das Trevas".

Figura 1 - Matéria jornalística sobre o nome Ribeirão das Trevas

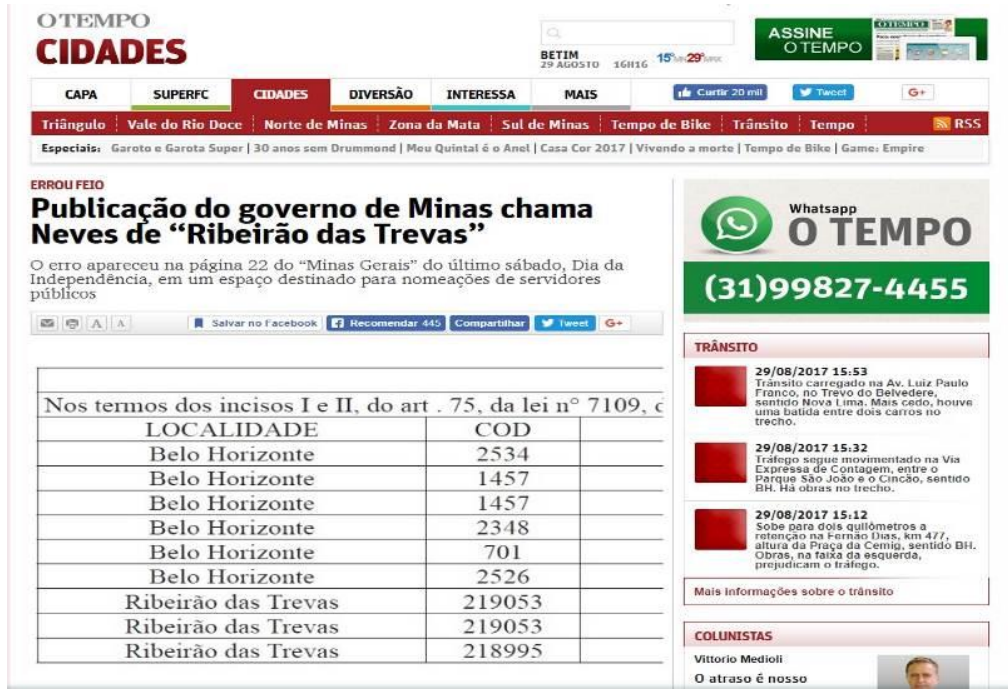

Fonte: Portal Online do Jornal O Tempo - MG, 11 de setembro de 2013.

Periferia, v. 12, n. 3, p. 322-346, set./dez. 2020 


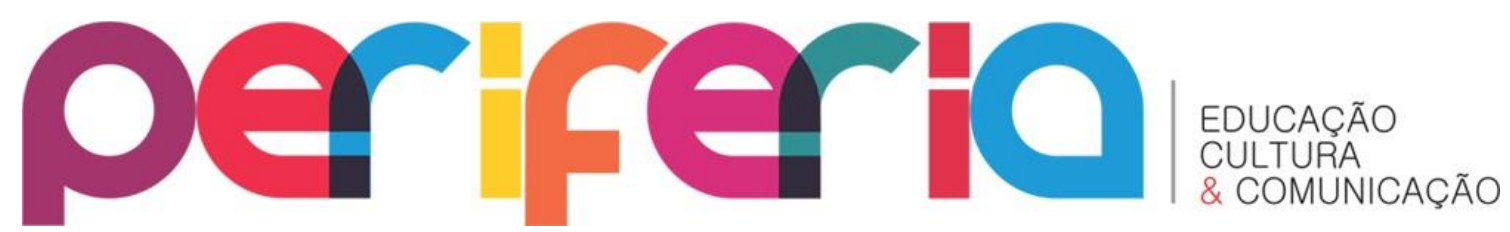

ISSN:1984-9540

DOI: $10.12957 /$ periferia.2020.49114

Essa publicação gerou um impacto muito negativo na população, que trouxe à tona uma grande discussão a cerca da identidade do cidadão nevense. Ribeirão das Neves é um município mineiro, localizado na região metropolitana e periferia da capital Belo Horizonte. De acordo com levantamento realizado pelo IBGE (Instituto Brasileiro de Geografia e Estatística), a população estimada em 2018 é composta por mais de $331 \mathrm{mil}$ habitantes em um território com extensão aproximada de $155.454 \mathrm{~km}^{2}$. No último censo realizado pelo IBGE em 2010, a população da cidade somava 296.317 habitantes e cerca de $60 \%$ autodeclarada negra (pretos ou pardos) ${ }_{1}^{2}$. Os dados também indicam que a maior parte da população possuía renda mínima ou nenhuma renda, permitindo classificar o município como sendo de pobreza absoluta segundo a Lei Orgânica da Assistência Social (LOAS). Além disso, indicadores do Índice de Desenvolvimento Humano 2010 revelam que a cidade está entre os 10 municípios mineiros mais dependentes do programa Bolsa-Família, sendo que $30 \%$ da população era considerada vulnerável à pobreza. Ainda segundo o IBGE, 74,3\% dos domicílios possuíam esgotamento sanitário adequado e apenas $8,5 \%$ dos domicílios urbanos estavam em vias públicas com urbanização adequada (presença de bueiro, calçada, pavimentação e meio-fio).

Muitas pessoas preferem esconder que moram na cidade por medo de perder oportunidades de emprego e renda, e muitas se unem ao discurso dominante numa tentativa de se desvencilhar do estigma nevense, pois dizer que "mora ali só enquanto não consegue um lugar melhor" é preferível a dizer que é um cidadão nevense e sentir orgulho disso. 0 conflito de identidade é também um conflito de pertencimento. Eu mesma me perguntei algumas vezes se poderia me apresentar como nevense, uma vez que na minha certidão de nascimento consta que sou natural de Belo Horizonte. Porém, basta parar uns minutos e analisar o que está por trás desse registro oficial de

\footnotetext{
2 Censo 2010 IBGE sobre Ribeirão das Neves: Dos 296.317 habitantes, 64.829 se declararam brancos; 142.325 pardos; 36.569 pretos; 4.346 amarelos e 613 indígenas. A pesquisa completa está disponível em: https://cidades.ibge.gov.br/brasil/mg/ribeirao-das-neves/panorama. Acesso em 10 de março de 2019.
} 


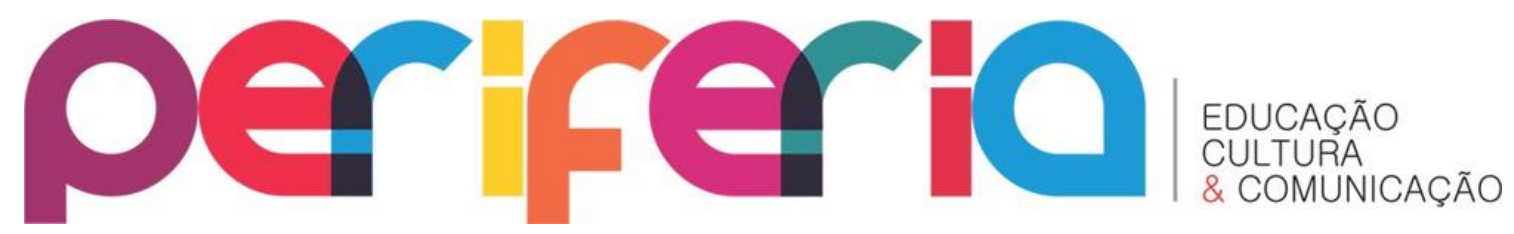

ISSN:1984-9540

DOI: $10.12957 /$ periferia.2020.49114 nascimento para entender que eu sou apenas uma dos milhares de pessoas que foram obrigadas a nascer em Belo Horizonte, por falta de opção. Segundo dados do Censo 2010 do IBGE, mais da metade da população (186.373 habitantes) não é natural da cidade, ou seja, nasceu em outros municípios.

Não se nasce em Ribeirão das Neves porque a única maternidade da cidade fica no Hospital Municipal São Judas Tadeu, que também é o único existente, e não consegue atender a demanda de saúde dos mais de $331 \mathrm{mil}$ habitantes. Nasci na capital e no dia seguinte já estava de volta a Neves, onde cresci e passei toda minha vida até agora, e ainda assim sou oficialmente uma belorizontina. Pode parecer um detalhe sem muita importância à primeira vista, mas em uma cidade com tantos desafios e um frágil elo de pertença com seus moradores, um registro oficial de nascença faz muita diferença.

Essas e outras ausências (ZALUAR, 2003) fazem parte do cotidiano dos moradores nevenses: ausência de espaços públicos de convivência, lazer e prática esportiva; ausência de incentivo à cultura e às artes; ausência de hospitais de qualidade para atender à demanda da população; ausência de escolas equipadas e estruturadas para oferecer qualidade aos professores e aos estudantes; ausência de ofertas de trabalho e geração de renda que obriga os moradores a saírem da cidade em busca de oportunidades nos municípios vizinhos; ausência de infraestrutura adequada para o trânsito de veículos automotivos e facilidade de acesso às demais regiões.

Em contrapartida, sobram apresentações oficiais por parte do Estado e da Imprensa Mineira que reforçam uma narrativa única representando o município de Ribeirão das Neves como um lugar das trevas. Haja vista as publicações oficiais feitas pelo Diário Oficial do Estado MG e pelo Portal do Tribunal de Justiça MG citando a cidade pelo trocadilho Ribeirão das Trevas; também é possível constatar a mesma história nas representações oferecidas pelos jornais, que privilegiam pautas sobre violência, pobreza e outros problemas da cidade em suas matérias. Além disso, basta uma pesquisa rápida na internet através do sistema de palavras-chave digitadas no site de busca 


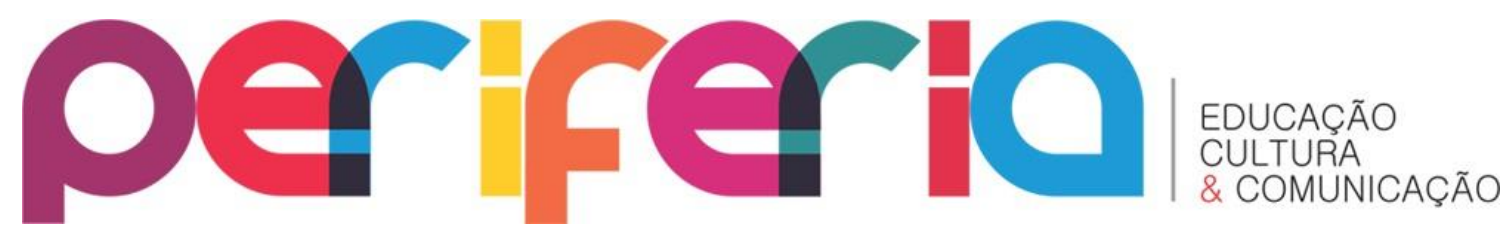

ISSN:1984-9540

DOI: $10.12957 /$ periferia.2020.49114

Google para encontrar mais elementos dessa mesma história. Digitando “Ribeirão das Neves" no buscador, encontra-se o seguinte:

Figura 2 - Print Pesquisa no Google

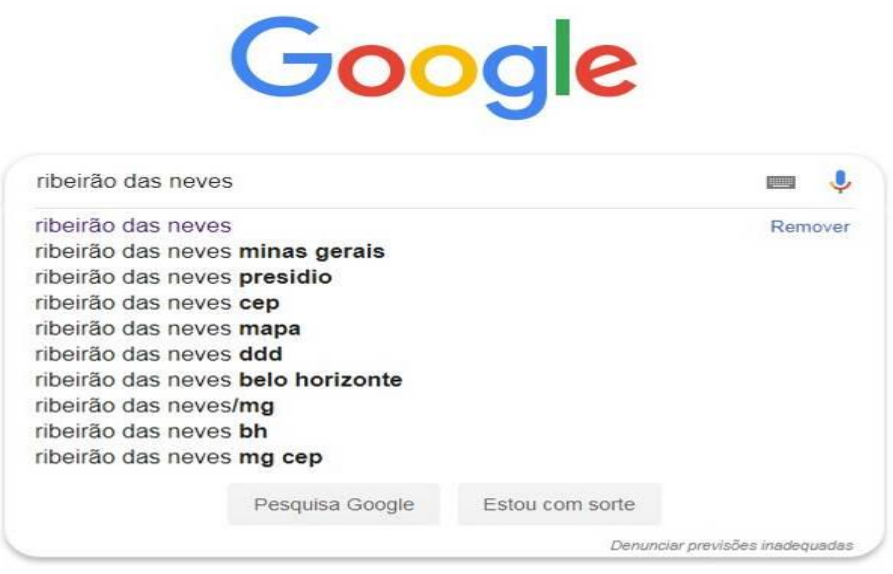

Fonte: Site de pesquisas Google, 2019.

Todas as palavras que aparecem são relacionadas a questões territoriais, como o estado de Minas Gerais, CEP, mapa, DDD, etc. Porém, a única palavra que aparece fora desse contexto geográfico e em segundo lugar no ranking de pesquisa é "presídio". Para completar a busca, digitando seguido ao nome da cidade o termo "notícias", o resultado encontrado revela todas as primeiras notícias ligadas a crimes, polícia e violência, além de encontramos uma sugestão de temas para pesquisa que o próprio site oferece, relacionando-os à palavra-chave digitada no momento da busca. Apenas essa pesquisa básica e rápida pela internet, que qualquer pessoa com acesso pelo celular consegue fazer, revela o assunto mais tratado pelos jornais quando se trata de Ribeirão das Neves. Desde veículos de comunicação locais e nacionais, o tema é sempre ligado ao medo e à violência.

O problema desse enfoque nas ausências, na violência e no medo que essa narrativa "das trevas" acarreta é o que a escritora nigeriana, Chimammanda Adichie (2009) chama de "história única”. Todo esse discurso em torno dos presídios e das ausências, repetido incansavelmente ao longo 


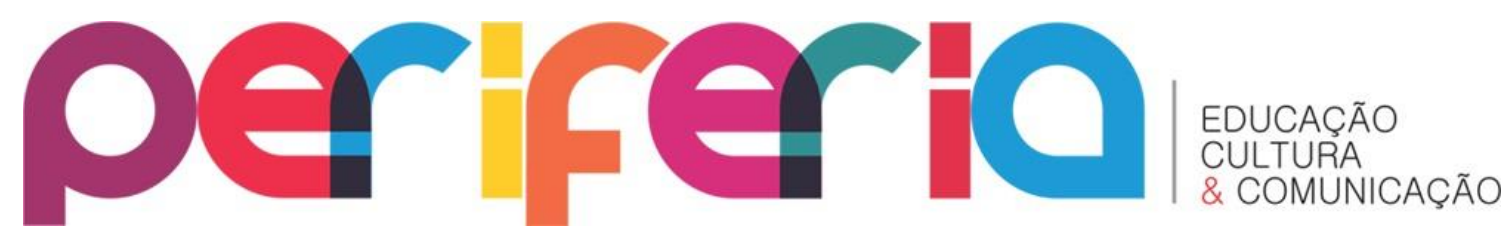

ISSN:1984-9540

DOI: $10.12957 /$ periferia.2020.49114 dos anos, criou sobre Ribeirão das Neves uma história única. Como se além das trevas, não houvesse mais nada. Esse sentimento experimentado se assemelha ao que Chimammanda contou em sua palestra sobre sua experiência com uma colega de quarto, no período em que estava na universidade nos EUA.

O que me impressionou foi que: ela sentiu pena de mim antes mesmo de ter me visto. Sua posição padrão para comigo, como uma africana, era um tipo de arrogância bem intencionada, piedade. Minha colega de quarto tinha uma única história sobre a África. Uma única história de catástrofe. Nessa única história não havia possibilidade de os africanos serem iguais a ela, de jeito nenhum. Nenhuma possibilidade de sentimentos mais complexos do que piedade. Nenhuma possibilidade de uma conexão como humanos iguais (ADICHIE, 2009).

Soma-se a esse contexto o fato de que a cidade formada por maioria da população negra e pobre, ainda convive com o estigma de ser o berço de seis unidades prisionais com mais de cinco mil detentos, incluindo o Presídio de Segurança Máxima Dutra Ladeira e o primeiro presídio do país na modalidade de parceria público-privado.

Figura 3 - Mapa das penitenciárias em Ribeirão das Neves

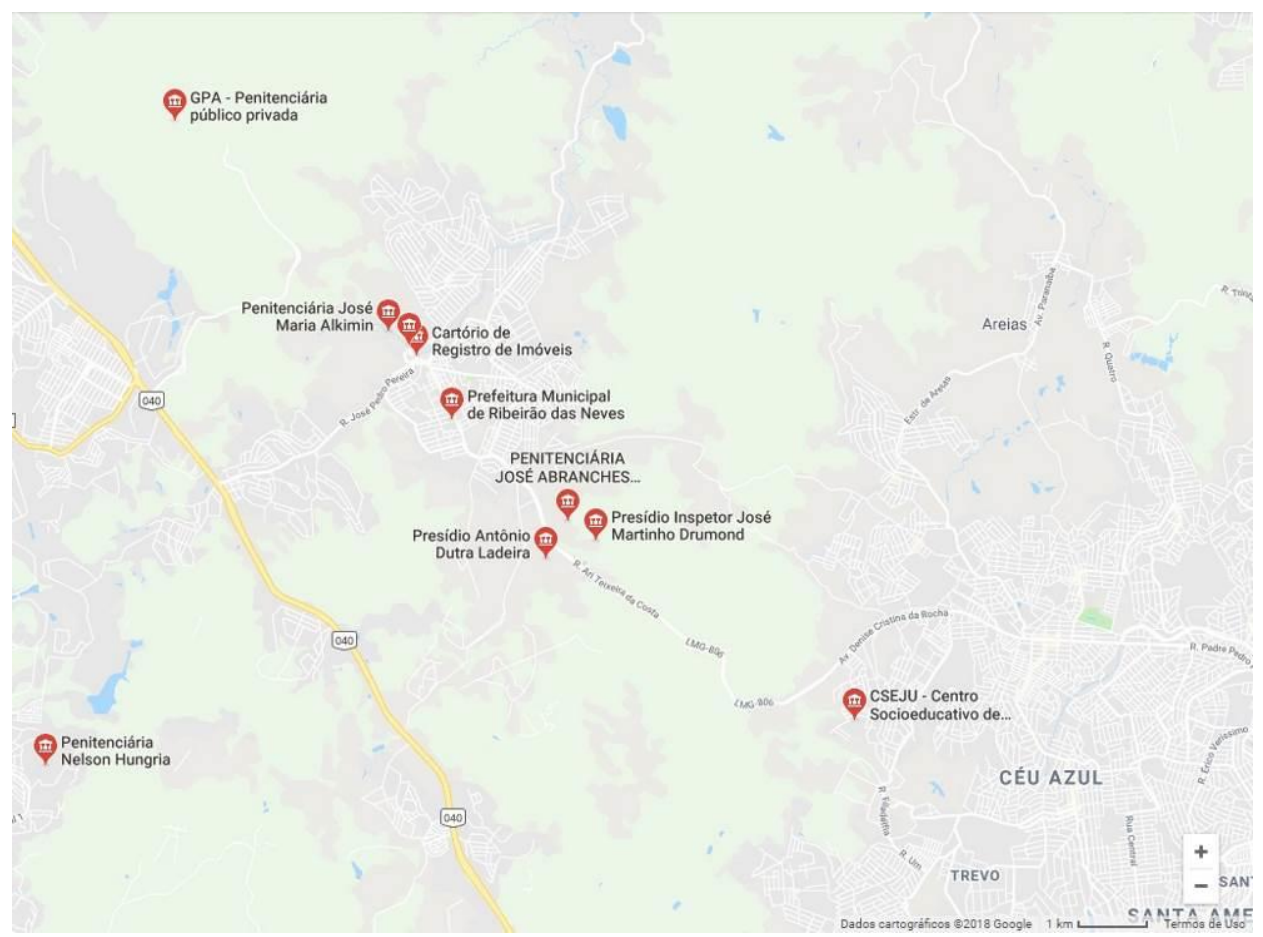

Fonte: Google Maps, 2018.

Periferia, v. 12, n. 3, p. 322-346, set./dez. 2020 


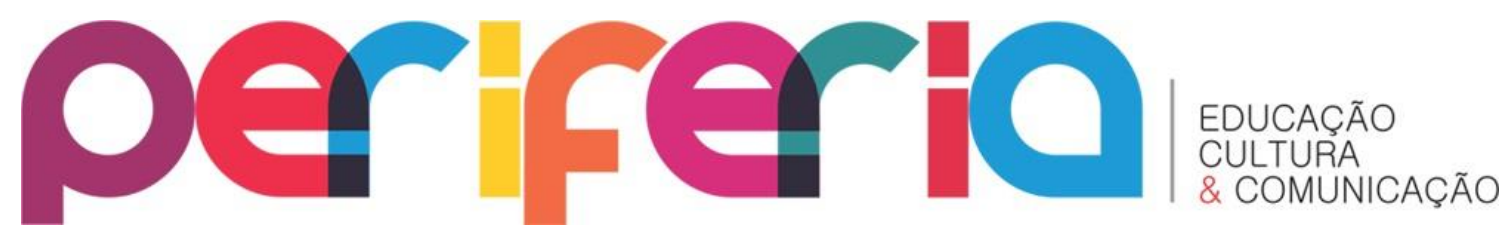

No mapa acima chama a atenção a quantidade de penitenciárias e, principalmente, a sua localização, pois elas não foram construídas em locais afastados dos centros urbanos. Ao contrário, estão próximas umas das outras e da região central. O Centro Socioeducativo para menores fica no bairro Felixlândia, ao lado de um Centro de Formação que oferece cursos para adolescentes e adultos e em frente a escola estadual Alessandra Salum Cadar. Outros três presídios ficam às margens da LMG 806, bem próximos ao Hospital São Judas Tadeu e à Prefeitura, via essa que continua até a Praça Central e termina no Presídio José Maria Alkimin, antiga PAN, localizado no coração da cidade. A exceção fica para a localização do mais recente Presídio GPA, fruto da parceria público-privada, que foi construído em um terreno mais afastado dos principais bairros do município.

Essas instituições foram construídas próximas umas das outras, e coexistem com os demais bairros em uma situação de normalidade, pois os moradores já se acostumaram aos seus muros como se fossem parte da paisagem local. Mas o comum é ouvir as mais variadas histórias e comentários que resumem a cidade aos presídios e à questão da insegurança pública. Por exemplo, em março de 2018, o apresentador Emílio Surita, do famoso programa de rádio "Pânico", atendeu uma ligação de um ouvinte que pediu para mandar um abraço pra um irmão de Ribeirão das Neves. Ao que o apresentador perguntou, dando risada: Ele está preso?

Um morador de Neves sabe que ao se apresentar em qualquer outro território, seja para trabalho, estudo ou lazer, o nome da cidade chega antes do seu próprio nome. E fala mais alto que sua própria voz. Se for uma pessoa negra, a situação é ainda pior, pois ser negro, pobre e morador da cidade dos presídios é quase uma carta que delimita os espaços em que se é permitido circular, as pessoas com as quais poderá conviver e o tipo de relação que poderá ser estabelecida. Essas identidades possíveis a quem pertence a Ribeirão das Neves, especialmente se tratando de uma cidade composta majoritariamente por uma população negra, limitam a liberdade e o direito, 


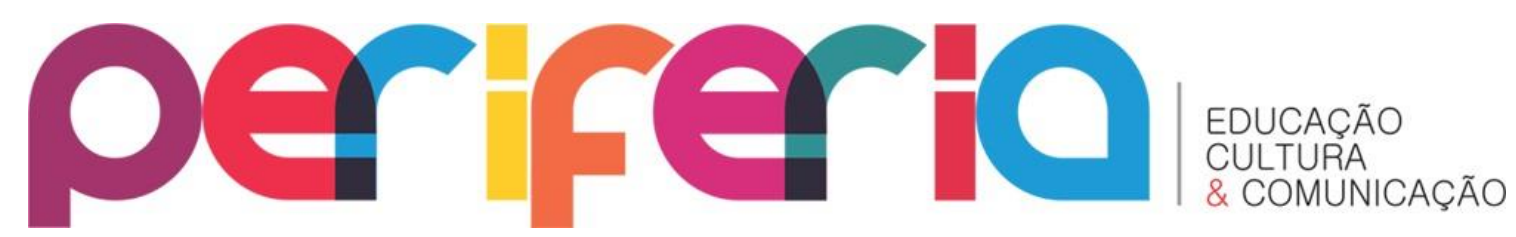

ISSN:1984-9540

DOI: $10.12957 /$ periferia.2020.49114 mesmo que a maioria dos mais de 300 mil habitantes não esteja realmente presa.

\section{“POR QUE VOCÊ TÁ TIRANDO FOTO DA GENTE?”}

Inicialmente, meu problema de pesquisa se resumia a investigar como as narrativas jornalísticas influenciavam a construção de identidades dos jovens da cidade de Ribeirão das Neves, com o intuito de responder se o discurso das "trevas" produzia algum impacto na autoestima das juventudes. o projeto ainda não estava muito bem definido, faltava um campo de pesquisa e um caminho mais consolidado.

0 processo de orientação, nesse sentido, foi fundamental para os rumos que esta pesquisa ganhou. 0 conhecimento de vida, trajetória acadêmica e sensibilidade da professora doutora e minha orientadora, Janaína Damaceno Gomes, ajudaram-na a perceber que mais do que respostas prontas e leituras indicativas de possibilidades metodológicas, eu precisava me encontrar comigo mesma como pesquisadora, e também fazer a experiência do encontro antropológico com meu campo de pesquisa. Na nossa primeira conversa, ela me pediu para apresentar a cidade e me fez uma pergunta: Como é Ribeirão das Neves? Então, sugeriu que eu utilizasse a fotografia, cujas técnicas me eram familiares devido a minha formação como jornalista, como um recurso tecnológico para mostrar a minha cidade a ela.

Com a missão de produzir um ensaio fotográfico sobre Neves, voltei para casa, tirei a câmera semiprofissional do armário e decidi sair um dia caminhando pelos pontos mais conhecidos para registrar como eu via as trevas e as luzes do meu lugar. Comecei logo no início da manhã pela minha própria rua e, enquanto tirava fotos, alguns moradores começaram a me abordar perguntando se era alguma reportagem, pois queriam aproveitar para reclamar. O caminho que tinha imaginado percorrer de certa maneira "solo" passou a ser modificado a partir das intervenções das pessoas do bairro. Acabei chegando à Pracinha do Felixlândia, no intuito de mostrar o descaso com o que deveria ser um local de lazer e convivência para os moradores. No

Periferia, v. 12, n. 3, p. 322-346, set./dez. 2020 


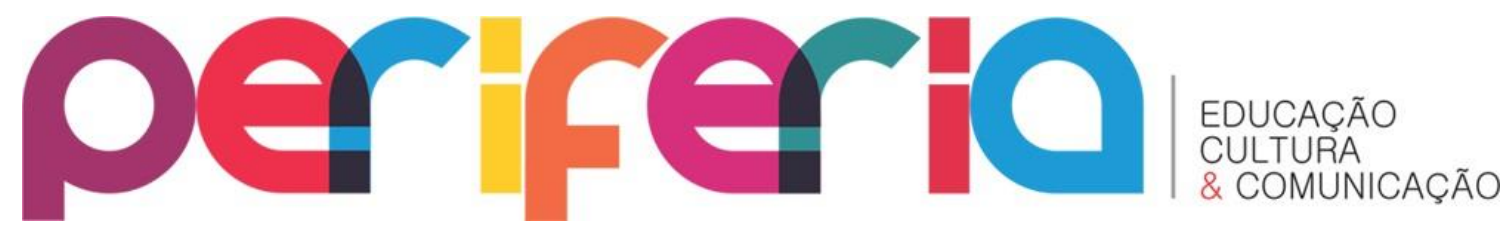

ISSN:1984-9540

DOI: $10.12957 /$ periferia.2020.49114 entanto, eu acabei tendo um encontro que mudaria completamente os rumos dessa pesquisa, ainda que não soubesse disso. Dois garotos estavam sentados conversando e precisei me aproximar e explicar minha intenção de fotografar, para o caso de eles não se sentirem à vontade em aparecer na imagem. Um dos garotos, que estava de bicicleta, falou que tinha vergonha e aproveitaria para ir embora, mas sugeriu que eu fotografasse seu amigo, que prontamente se candidatou a posar no que ele chamou de "minha pracinha", e mais tarde, eu chamei de "A pracinha do Nathan":

Figura 4 - Pracinha do Nathan

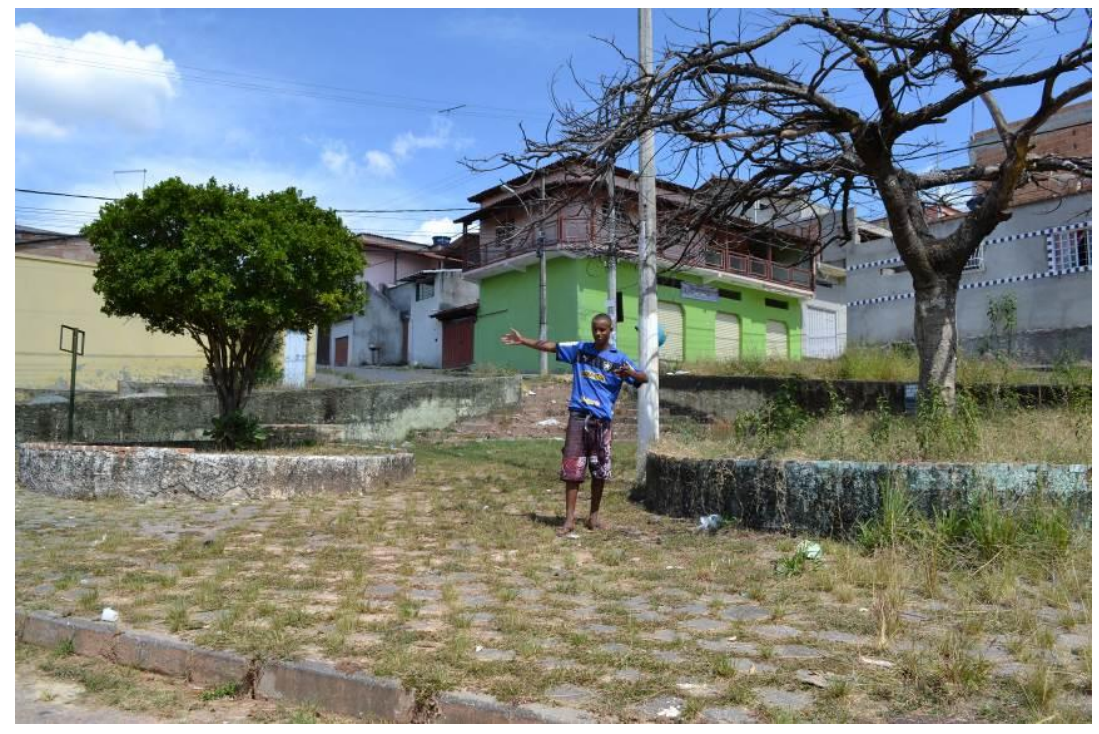

Fonte: Rafaela Goltara, 2018.

Conversamos alguns minutos, enquanto eu explicava o motivo das fotos e acabamos falando informalmente sobre as Trevas do Ribeirão. Nathan contou que era novo na cidade e que ainda estranhava o fato de não ter nada para fazer, apontando como a pracinha que deveria ser uma opção de lazer estava coberta de mato e lixo nos canteiros. O tema do lixo me lembrou do lixão a céu aberto, que me levou às ruas do bairro Viena e, ao Centro Socioeducativo localizado na região; em seguida à LMG 806, via de acesso ao centro da cidade em que também fiz uma parada para fotografar os presídios ao longo da estrada. A câmera fotográfica acabou funcionando como um bilhete de acesso aos locais e atraindo a atenção de pessoas que pediam para

Periferia, v. 12, n. 3, p. 322-346, set./dez. 2020 


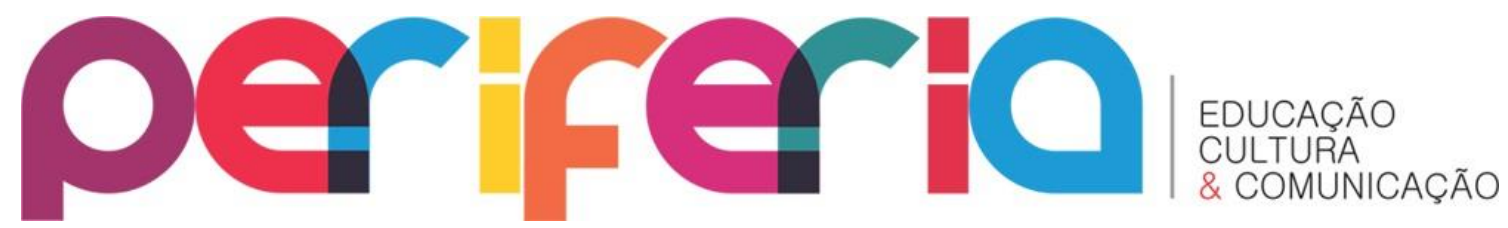

ISSN:1984-9540

DOI: $10.12957 /$ periferia. 2020.49114 serem fotografadas, contavam suas histórias ou aproveitavam para fazer algum tipo de lamento sobre o descaso político com as questões da cidade. Todos esses encontros me levaram, já no entardecer, à Praça de Justinópolis (principal praça da cidade localizada próximo à divisa com Belo Horizonte). Vi alguns jovens andando de skate no estacionamento da Igreja e resolvi fazer uma fotografia:

Figura 5 - Skatistas no estacionamento da Igreja

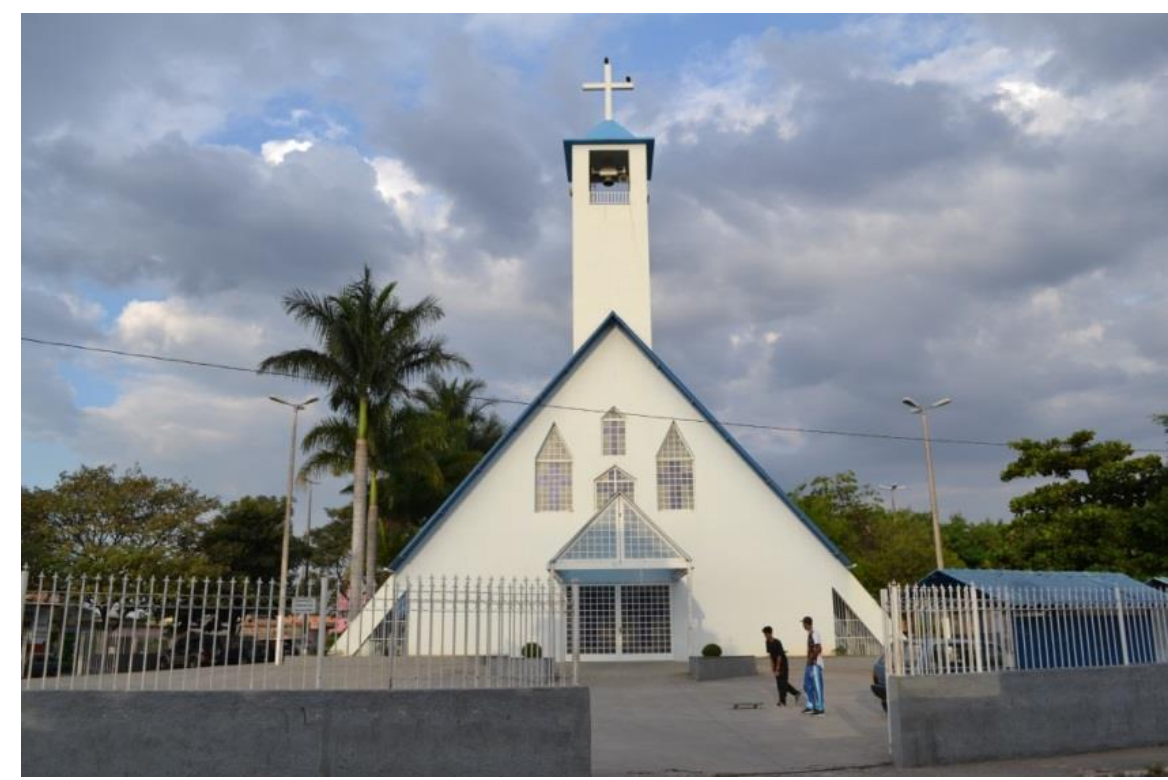

Fonte: Rafaela Goltara, 2018.

O barulho do flash chamou a atenção dos rapazes, que se aproximaram desconfiados perguntando por que eu estava tirando foto deles. Antes que eu me explicasse, o mesmo jovem Nathan que eu havia encontrado mais cedo, coincidentemente, estava no local, me reconheceu e acabou participando e mediando a conversa. Ele me apresentou como sua amiga, dizendo que eu estava pesquisando sobre a cidade e já havia inclusive o entrevistado. Interessados, os outros dois jovens (Alexandre e Wesley) se apresentaram e acabamos os quatro sentados no chão conversando sobre a ideia da minha pesquisa que ainda não estava completamente formada.

0 resultado desse encontro foi a descoberta do grupo de skatistas Just Crew Skateboard, do qual eles faziam parte, que utilizava o coreto da praça e, mais recentemente, o estacionamento da igreja como pista para seus 


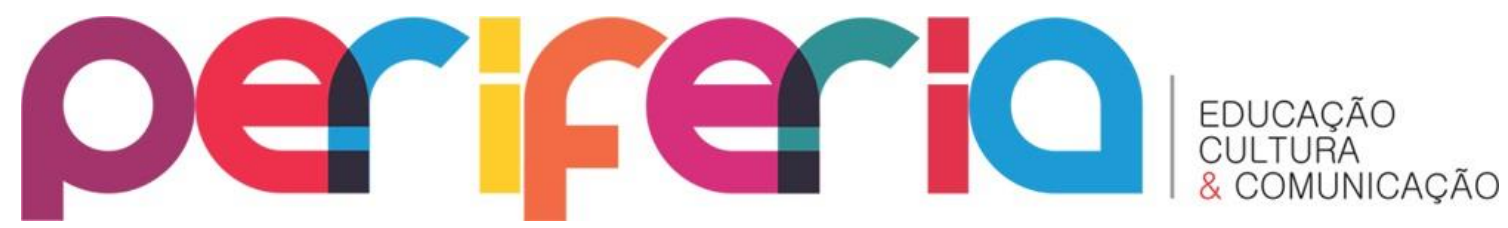

ISSN:1984-9540

DOI: $10.12957 /$ periferia.2020.49114 skates. O grupo reformou a praça e o coreto, adaptando o local com obstáculos construídos por eles próprios para a prática esportiva do skate. Reúnem-se, ensinam uns aos outros e divulgam a modalidade na região desde os anos 2000, e me disseram que tinham interesse em me contar a história do grupo para quem sabe serem eles os protagonistas da minha pesquisa. Convocaram os demais da crew para um novo encontro no dia seguinte e me pediram para levar a câmera a fim de gravar o bate papo coletivo.

No dia seguinte, nos encontramos novamente e a câmera fotográfica funcionou como filmadora, pois eles queriam gravar seu relato de forma conjunta, como numa grande roda de conversa, e para que eu pudesse acompanhar o grupo de forma mais íntegra optei por filmar todo nosso papo. Ao término da gravação, eles pediram para que eu aproveitasse a câmera a fim de tirar uma foto de todos que estavam lá, e criaram um grupo no whatsapp para que eu compartilhasse o material audiovisual com eles. Isto porque a Just Crew possui redes sociais ativas que ajudam a divulgar o trabalho para outros jovens e para possíveis colaboradores, dessa forma, as imagens serviriam de conteúdo e visibilidade ao grupo.

Figura 6 - Foto da Just Crew Skateboard ao término da gravação

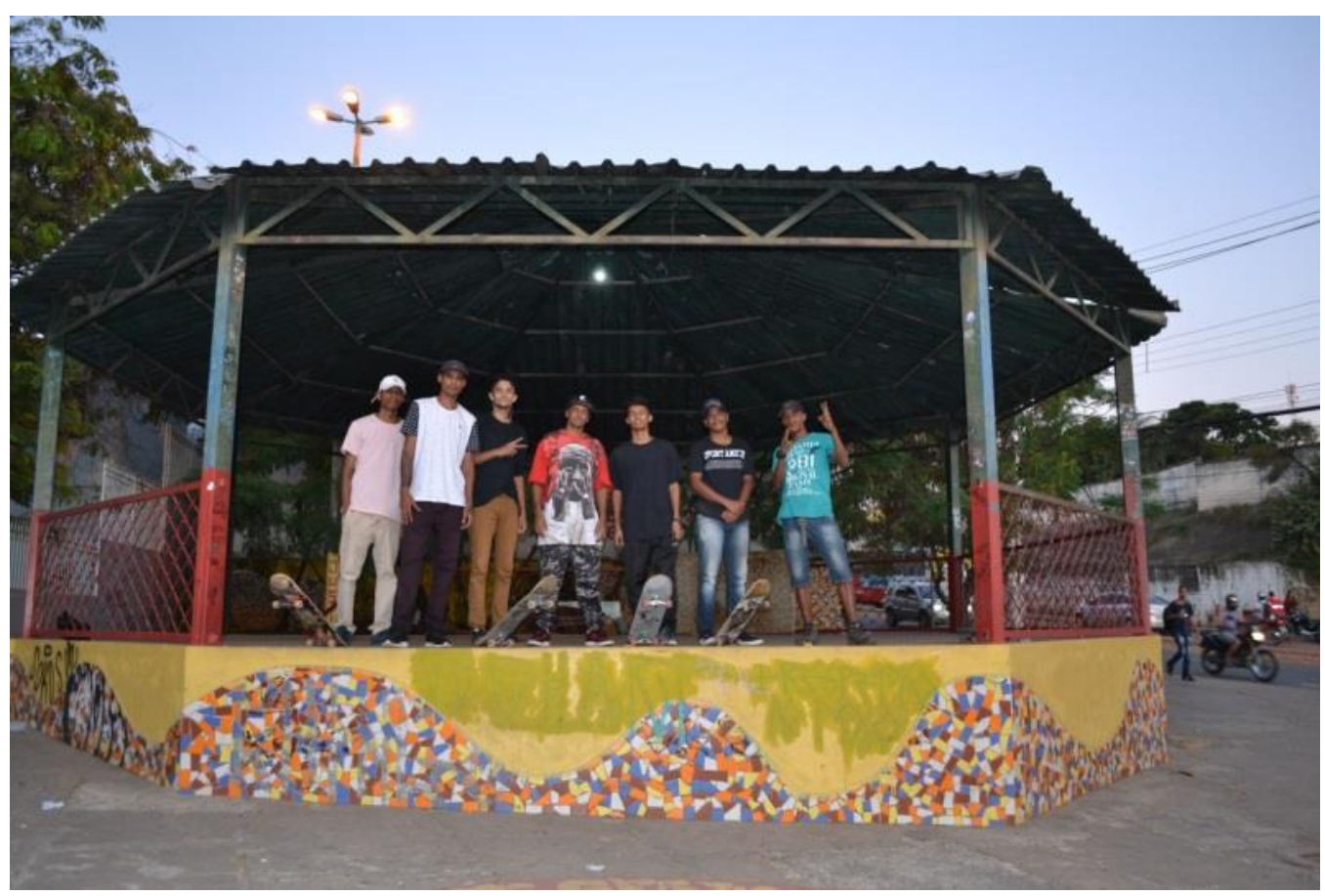

Fonte: Rafaela Goltara, 2018.

Periferia, v. 12, n. 3, p. 322-346, set./dez. 2020 


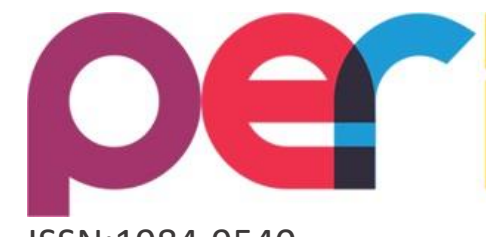

ISSN:1984-9540

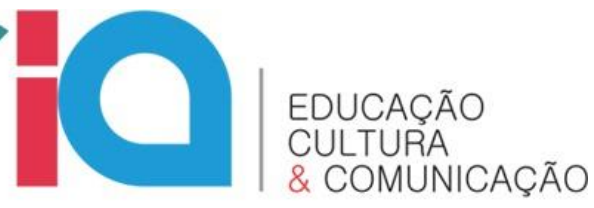

DOI: $10.12957 /$ periferia.2020.49114

Voltei para a FEBF (UERJ) com uma centena de fotos e algumas horas de gravação com os skatistas, além de uma boa dose de ansiedade sobre como começar e direcionar a pesquisa. Eu não sabia se poderia utilizar as gravações e nem as fotografias no texto da dissertação, e ainda não havia compreendido a magnitude desse encontro, pois ainda me preocupava se estava fugindo da ideia central do projeto de pesquisa aprovado. Foi a partir desse momento que Janaína me olhou e me disse: "Você percebe que essa narrativa oficial não determina nada para eles? São os skatistas que estão influenciando a cidade contando outra história, uma história bem mais interessante do que as trevas do Ribeirão". Essa frase me tocou profundamente, mesmo que eu não tivesse compreendido totalmente naquele momento. Ela continuou me olhando e emendou: "Que maravilha, você encontrou o seu campo! Agora escreva tudo da mesma maneira como me contou, me conte essa história no papel, dê movimento a ela assim como o skate." E assim nasceu essa dissertação, de uma câmera, um encontro e uma fotografia.

Depois de toda essa escrita, Janaína passou a me apresentar autores e estudos que me ajudavam a compreender e analisar melhor todo o material que eu tinha em mãos. Compreendi que tinha feito um processo conhecido como "descrição densa", termo utilizado por Clifford Geertz (1978) para explicar o processo etnográfico dentro do campo da Antropologia. Para entender melhor se a Etnografia era mesmo o caminho metodológico que eu estava percorrendo, me inscrevi em uma aula sobre etnografia, além de buscar também conhecer o trabalho de José Guilherme Magnani (2002) que propõe uma etnografia urbana, um jeito de pesquisar com um olhar "de perto e de dentro", que valorize tanto os atores sociais que serão estudados quanto a paisagem em que a atividade se desenrola como sendo parte constitutiva da situação em análise.

Acabei conhecendo também o trabalho de Janice Caiafa (2007), que sugere uma abordagem metodológica da etnografia da simpatia, e foi esse o conceito que mais tocou meu coração e fez sentido para a experiência que 


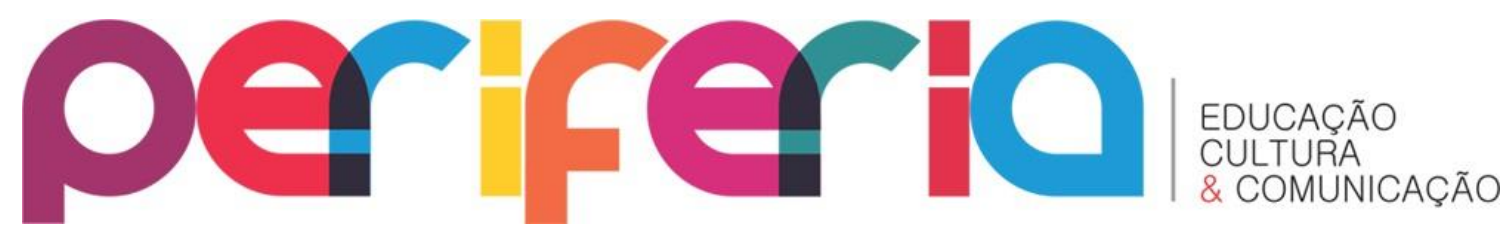

ISSN:1984-9540

DOI: $10.12957 /$ periferia.2020.49114 estava sendo tecida entre esta pesquisadora e os skatistas nevenses. A palavra simpatia tem origem no latim e significa “comunhão de sentimentos". De acordo com o Portal Origem da Palavra ${ }^{3}$, é derivada de Sympatheia, SYM (junto) + PATHOS (sentimento), e poderia ser compreendida como a “capacidade de sentir o mesmo que outrem, de ser afetado pelos sentimentos alheios (positivos ou negativos)". Para Caiafa, experimentar a simpatia é como romper os limites da própria identidade, saindo de si e indo para fora ao encontro dos outros, criando uma nova relação de agenciamento.

Para de alguma forma encontrar os companheiros de campo, é preciso apenas ter algo a ver com eles, alguma coisa para agenciar com eles. Para realizar isso, seria preciso, de novo, uma disposição para se deixar afetar pelo que nos cerca, de forma que a identidade a que estamos habituados não nos impeça de partilhar as paixões ali presentes (Caiafa, 2007, p. 154).

Eu tinha algo a ver com eles, também sou uma jovem moradora de Ribeirão das Neves e convivo com as mesmas intempéries e a mesma narrativa oficial que me segue e me apresenta antecipadamente em todos os lugares. No entanto, apesar dessa primeira coisa a se agenciar com eles, a câmera fotográfica que foi o verdadeiro algo a nos aproximar, fez com que eles me afetassem de uma maneira transcendental diante da paixão que eles nutriam pelo skate e uns pelos outros. Nós passamos a compartilhar não só os sentimentos relacionados ao nosso território e nossa experiência de vida como nevenses, como também compartilhamos fotografias, câmera, olhares. Essa comunhão de sentimentos foi o que possibilitou que essa experiência etnográfica ganhasse poesia no ato de compartilhar imagens e olhares, meus com eles, eles comigo, olhares deles e meu para a cidade, e da cidade para eles, para mim e para nós. O que aconteceu conosco foi a descoberta da imagem como simpatia, um novo jeito de olhar e de ser olhado, de compartilhar e entrar em comunhão com sentimentos alheios, uma nova forma de fazer pesquisa e etnografia.

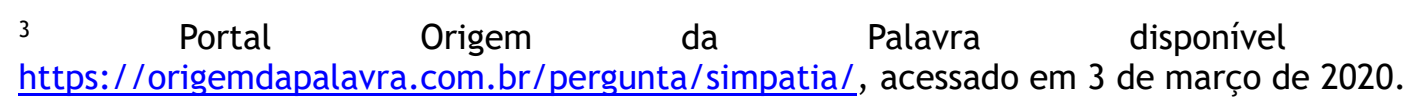

Periferia, v. 12, n. 3, p. 322-346, set./dez. 2020 


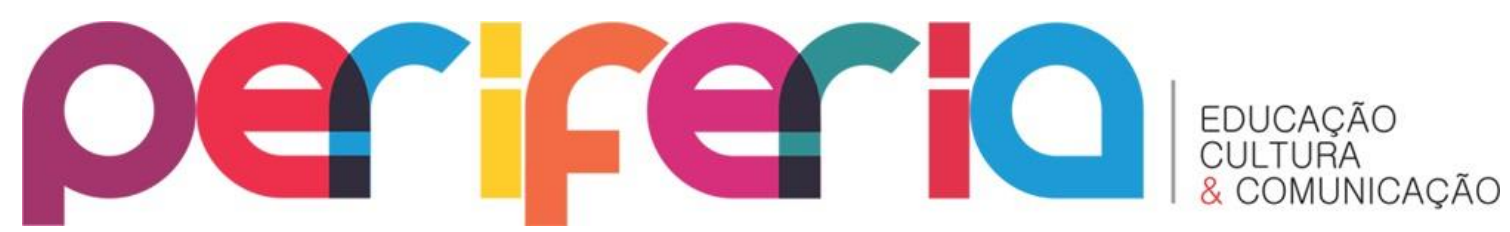

ISSN:1984-9540

DOI: $10.12957 /$ periferia.2020.49114

De acordo com Janice Caiafa (2007), a etnografia tem origens nos estudos sociológicos e, posteriormente, na Antropologia. É um tipo de pesquisa que permite ao pesquisador se incluir no processo; não só analisar dados colhidos em campo, mas participar da construção desse conhecimento.

A inclusão do pesquisador na situação que ele investiga é um aspecto inarredável da pesquisa etnográfica, já que ela envolve observação intensiva e em algum grau, uma convivência. Partilhar uma experiência complexa com os informantes ou companheiros - com os "outros" que encontramos no campo - vem sendo uma marca da pesquisa etnográfica (CAIAFA, 2007, p.38).

O trabalho de campo acabou me incluindo no processo de forma surpreendente, mesmo que eu só tenha me dado conta disso depois de já ter assumido o que Caiafa (2007) chama de "atitude etnográfica", uma forma de estabelecer uma relação com o outro que está sendo pesquisado e de se colocar na pesquisa também. Para ela, essa "atitude" é um "métodopensamento" que permite que a etnografia possa ser transferível a outras áreas do conhecimento. Como é o caso desta pesquisa, que está situada no campo da Educação, mas em diálogo aberto com os estudos sobre Cultura, Comunicação e, agora, com a Antropologia, permitindo que esse fazer etnográfico conduzisse essa investigação.

Quando comecei a olhar as fotos que havia tirado no encontro, me senti uma versão feminina de Sebastião Salgado e fiquei encantada com as imagens capturadas. Porém, quando compartilhei com os demais, recebi uma chuva de perguntas como "Com quem você compartilhou essas fotos?", "Você pode voltar amanhã?”, e outros tantos comentários de “Meu Deus, que droga!”, “Nossa, vai queimar nosso filme isso daí”. Eu fiquei tão decepcionada e não conseguia compreender o motivo de não terem gostado daquelas imagens que pra mim eram lindas. Mas eles me explicaram que como fotógrafa de skatistas, eu era péssima. Porque o importante era mostrar o tipo de pulo e manobra que eles estavam realizando, e que estivesse bem feito para que outros skatistas pudessem admirar e não criticar. Além disso, as imagens gravadas não poderiam ser de um ponto fixo, como eu tinha realizado, mas 


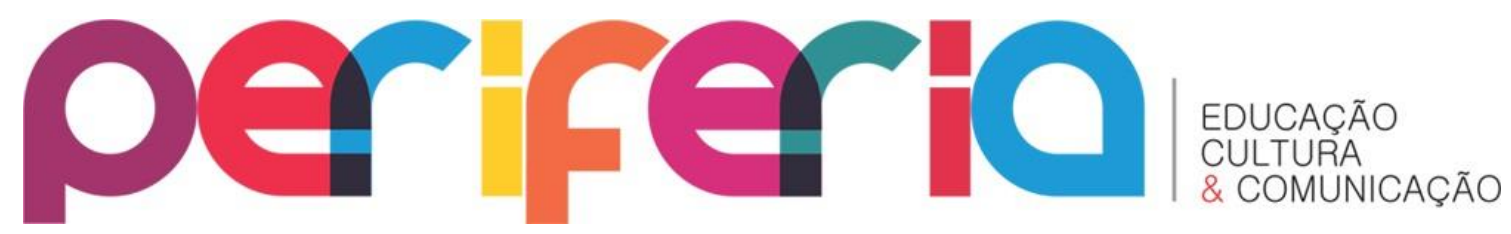

ISSN:1984-9540

DOI: $10.12957 /$ periferia.2020.49114 deviam acompanhar todo o movimento que o skatista faz com seu shape do início ao fim, revelando a técnica utilizada.

Figura 7 - De 50 imagens, a única aprovada por eles para utilização

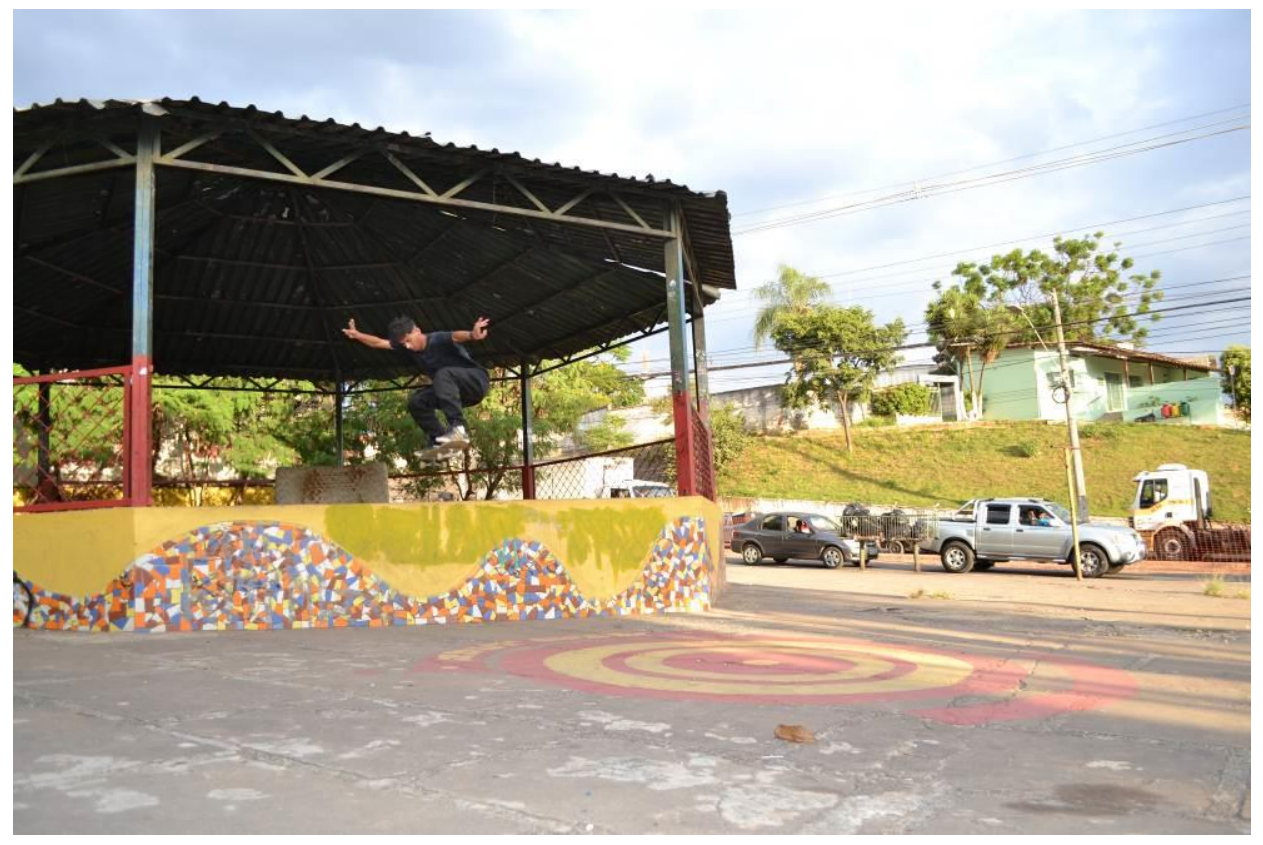

Fonte: Rafaela Goltara, 2018.

Esse encontro foi o que me transformou em pesquisadora e devo isso à generosidade da Just Crew em compartilhar comigo suas experiências e conhecimentos, e me permitirem trocar com eles também. O grupo no whatsapp deixou de ter apenas a função de enviar as fotos daquele dia e passou a ser um espaço de diálogo entre nós, até que da conversa surgiu a ideia de produzirmos um documentário sobre a cidade a partir do olhar do grupo. Como eu estava morando no Rio de Janeiro e não poderia acompanhálos naquele período, deixei minha câmera fotográfica com o Alexandre para que eles mesmos fizessem as imagens e gravações que achassem importantes. O resultado é percebido nos vários vídeos de manobras radicais que eles produziram, em seus mais variados graus de dificuldade e imagens qualificadas porque foram feitas pelo olhar técnico de skatistas.

Assim, essa pesquisa ganhou os contornos construídos de forma coletiva e a investigação sobre as narrativas da cidade mudou de perspectiva, pois 


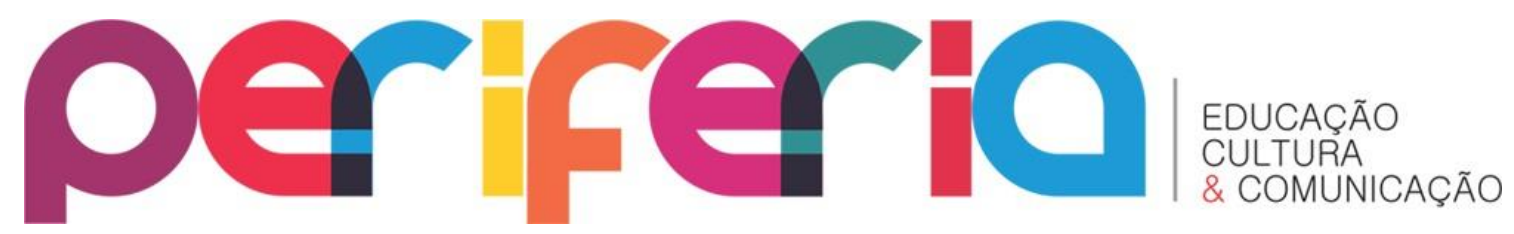

ISSN:1984-9540

DOI: $10.12957 /$ periferia.2020.49114 enfim começou a fazer sentido a fala da minha orientadora de que não eram eles os afetados e influenciados pela dominância das narrativas das trevas e ausências, de forma passiva, mas sim os que entravam em disputa assumindo um novo poder de contar outra história sobre a cidade. A Just Crew também mudou minha concepção sobre o papel da fotografia nesse fazer metodológico, pois não era mais apenas uma questão de analisar as representações contidas nas fotos e o modo como foram criadas, mas o simbolismo contido no simples gesto de apontar uma câmera fotográfica para dois garotos numa praça.

Ao olhar as fotografias do grupo, o que primeiro fica visível é a imagem deles próprios: homens, jovens, negros, skatistas. O que essa imagem diz? De acordo com Sylvia Caiuby Novaes (2008, p.463), “ao contemplar uma foto, frequentemente o que se vê não é apenas o que ali está representado pela intenção do fotógrafo, mas o que ela evoca no universo das experiências pessoais de quem a contempla". No entanto, muitas vezes somos levados a interpretar fotografias como cópias idênticas da realidade.

Esse conflito é compreendido pela autora como originado na capacidade que a fotografia tem de estar bem mais próxima do que apresenta do que as palavras em um texto, por exemplo, como se fosse um efeito de mágica. Para ela, "além da semelhança entre a imagem e o real que ela representa, na fotografia o referente adere à imagem tal como nas práticas mágicas, em que se supõe que qualquer elemento que tenha tido contato com uma pessoa possa, pelo contágio, remeter a ela” (Novaes, 2008, p. 462). Dessa forma, as fotografias assumem a capacidade de nos iludir com a ideia de natural e transparente que transmitem, escondendo "os inúmeros mecanismos de representação de que resultam".

Tirar uma fotografia não é, então, uma forma de capturar a realidade de forma transparente e natural. É um ato discursivo, que tem poder de criar significado e simbolismos sobre o que se está retratando, portanto, não é difícil entender porque apontar uma câmera para alguém pode gerar desconforto e desconfiança. Guilhermo Aderaldo (2013) chamou a atenção em 


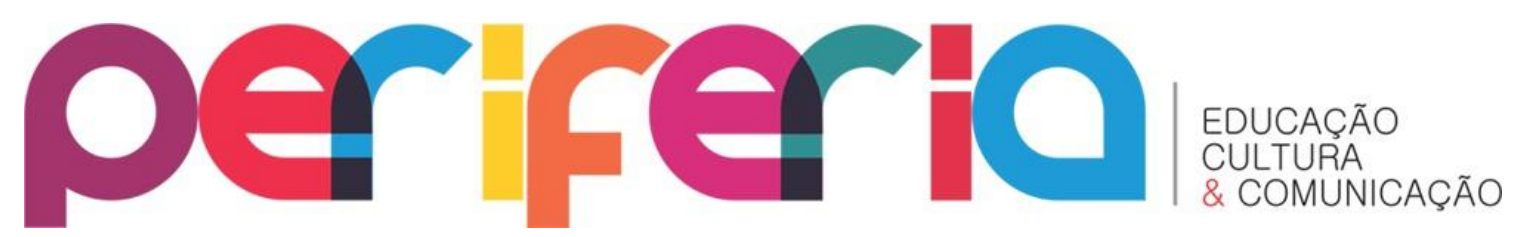

ISSN:1984-9540

DOI: $10.12957 /$ periferia.2020.49114 sua pesquisa com grupos de produtores de audiovisual em coletivos culturais de São Paulo para a importância da construção e disputa simbólica de imagens pelos próprios jovens moradores de periferias e produtores que se identificam com a periferia.

Ele destaca como o tema "periferia" passou a despertar o interesse mercadológico num tom crescente que envolve financiamentos e negociações em dinheiro, e como os produtores da/na periferia constroem e desconstroem esse conceito de formas distintas, dependendo do contexto em que estão inseridos e do que pretendem alcançar, desmistificando a noção de senso comum que se instaurou nas produções do cinema nacional sobre a lógica de separação entre centro e periferia. "O que eles realmente fazem, para além de uma simples ressignificação do termo "periferia”, conforme eu supunha no início da pesquisa, é relativizarem a ideia de “centro"” (Aderaldo, 2013, p.328).

Todo esse interesse que, de repente, as universidades e produtores audiovisuais começaram a demonstrar em territórios e pessoas relegadas ao esquecimento e invisibilidade por tanto tempo causa estranhamento. Rose Satiko Hikiji (2009, p. 120) relata os desafios que encontrou quando resolveu fazer uma etnografia desenvolvendo um filme como antropóloga e fomentando a produção de outro filme para um grupo da "quebrada". "Em diversos momentos, ouvi questionamentos acerca do lugar do antropólogo/documentarista que quer falar sobre eles, sobre o movimento que protagonizam. Nestes momentos, eles defendem a posição de que podem falar e, de fato, falam sobre si próprios".

Novaes (2008) então, propõe que a imagem seja utilizada como um recurso enriquecedor para a escrita antropológica, porque oferece a possibilidade de compartilhar com os leitores um pouco da experiência do pesquisador com a cena retratada, ao mesmo tempo em que não conclui e nem determina a cultura. Ela acredita que as conversas que temos com nossos interlocutores no campo não são a principal fonte de aprendizado, e sim a experiência que esse encontro proporciona. As imagens utilizadas na escrita 


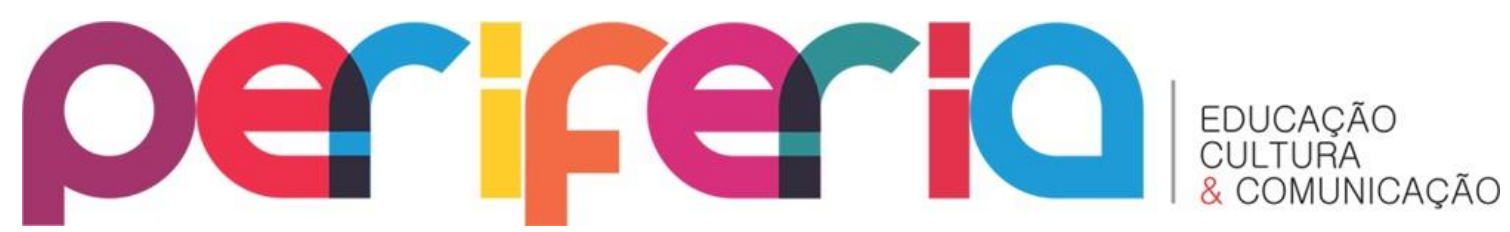

ISSN:1984-9540

DOI: $10.12957 /$ periferia.2020.49114 antropológica podem oferecer conhecimento por meio da familiaridade, assim como o texto oferece pela descrição.

E na evocação através das imagens, o papel do receptor é fundamental. Neste novo conceito de conhecimento antropológico, o significado não resulta apenas de uma reflexão sobre a experiência; ele necessariamente inclui a experiência - talvez de modo algo próximo àquele de alguém que se submete às práticas mágicas (NOVAES, 2008, p. 471)

Então, o que essa fotografia dos jovens com seus skates posando no coreto da praça quer nos dizer? A cultura, a experiência de vida de cada espectador irá, com certeza, produzir interpretações das mais diversas. O que você vê quando olha pra ela? Eu, quando vejo essa foto, não consigo desassociá-la da experiência do nosso encontro e de tudo que eles partilharam. Homens negros, jovens, moradores de uma periferia conhecida por seus presídios e pauta dos jornais e das piadas maldosas de motoristas de uber e moradores de cidades vizinhas, quando estão parados em uma praça da cidade no meio da tarde recebem primeiro os olhares de desconfiança, de medo, de julgamento. Inúmeras vezes são abordados pela polícia ou repelidos por transeuntes que trazem nos olhos o aprendizado do estereótipo: "na certa são marginais ou estão usando drogas".

O tempo todo em que estão na praça, eles precisam se proteger e procurar parceiros de "notável credibilidade" para evitar serem reprimidos pela polícia, que passou de carro, várias vezes, nos encarando somente no curto período em que estive com eles gravando a conversa. Parceiros como o padre da Igreja que cedeu o estacionamento para que eles praticassem com mais segurança, comerciantes locais e familiares que os conhecem e oferecem apoio numa tentativa de desmistificar o rótulo de menores desocupados vandalizando a praça. Quando eu apareci, de repente, apontando a lente da minha câmera fotográfica sem trocarmos nem uma palavra, foi como se também apontasse o dedo que os revela na clandestinidade. 0 ângulo escolhido, o posicionamento diante da cena vista já me permitem criar uma narrativa sobre aqueles garotos, pois a fotografia tem a capacidade de fazer um recorte da realidade e transpor o tempo. Assim como a narrativa oficial 


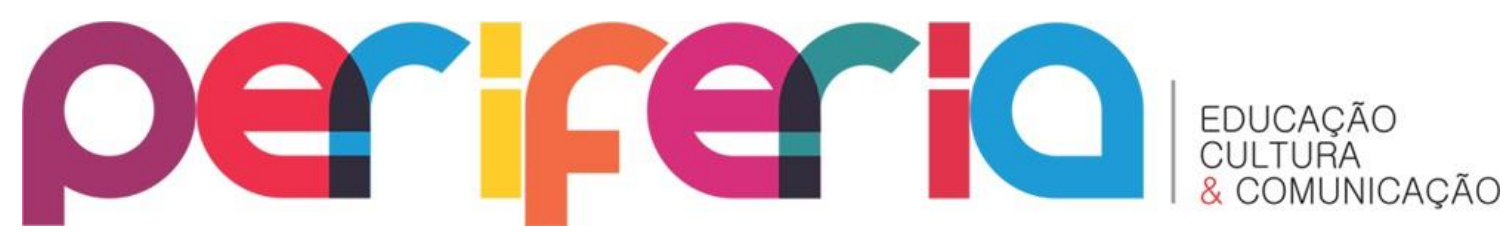

ISSN:1984-9540

DOI: $10.12957 /$ periferia.2020.49114 que apresenta imagens, sons e palavras atravessando o tempo e as gerações e marcando a cidade de Ribeirão das Neves como um lugar das trevas.

Se o encontro etnográfico consiste em um relato de experiências vividas e compartilhadas, fotografias enquanto meios e produtos dessa experiência fornecem pronunciamentos visuais dos indivíduos portadores e criadores de suas culturas e do etnógrafo que recria um universo de sentido (BITTENCOURT, 1994, p. 239).

No meu caso e da experiência dessa etnografia, acredito que na verdade foram os skatistas que me encontraram com sua simpatia e me incluíram no processo de se autorrepresentarem e compartilharem suas experiências comigo. A empatia, como diz Caiafa (2007), é por vezes supervalorizada como uma virtude de se colocar no lugar do outro e sentir como o outro se sente. Mas, como etnógrafa, seria uma pena se eu ousasse me colocar no lugar deles e assumir para mim suas palavras e sentimentos. Não só as fotografias trazem o pronunciamento visual da Just Crew, mas também a câmera fotográfica e como ela passou de objeto de intimidação para facilitadora de uma relação de simpatia que transformou e enriqueceu esse relato etnográfico.

Bendita seja a simpatia, a capacidade de se sentir atraído e se identificar com algo no outro. Bendita seja a simpatia antropológica de assim, com o coração aberto a trocar, conhecer e agenciar com o outro, poder trazer para dentro da universidade o espaço de diálogo honesto e interessado, a vontade de aprender com o outro e a possibilidade de lançar novos olhares sobre o mundo. Bendita seja a imagem como simpatia, como forma de compartilhar sentimentos, conhecimentos e possibilitar a experiência de transcender a história única sobre o mundo. A experiência e as imagens produzidas nesse encontro etnográfico contam outras histórias, outras formas de olhar e de ser visto, outras maneiras de (re)existir.

Periferia, v. 12, n. 3, p. 322-346, set./dez. 2020 


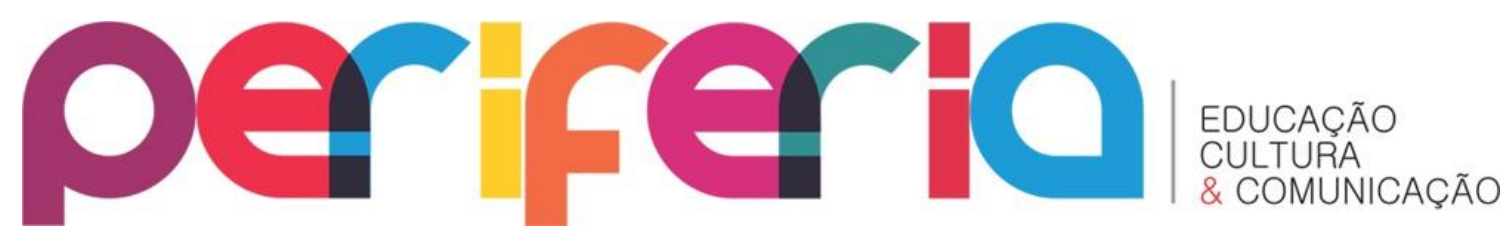

\section{CONSIDERAÇÕES FINAIS}

O interesse das universidades nas periferias e nos grupos e movimentos sociais como objetos de pesquisa não é novo. A etnografia como método de pesquisa tem origem em pensamentos que reforçam a história única dos colonizadores mundo a fora, pois era uma forma de "conhecer" os grupos considerados fora do padrão dos ditos normais, os exóticos. As favelas e periferias urbanas brasileiras por muito tempo foram esse exótico explorado como objeto para análises e formação de teorias, sempre de olhares externos e partindo de classes dominantes. A novidade está é na entrada desses sujeitos antes tidos como meros "informantes" nas universidades, assumindo lugares de fala, de produção de conhecimento, de questionadores da ordem e das normalidades habituais. E é impossível que as metodologias de pesquisa continuem as mesmas se as pessoas que fazem perguntas agora são outras.

Quando a Janaína sorriu ao ver as fotos e me ouvir contar a história sentada num banquinho do corredor da FEBF em Duque de Caxias, ela não só me disse que eu tinha feito um encontro antropológico com o campo de pesquisa. Ela, como representante de uma Universidade Estadual reconhecida, legitimou não apenas o meu trabalho como pesquisadora, como legitimou os skatistas como atletas e artistas, como produtores de um conhecimento inovador que seria lido por outros "pares" como tendo valor acadêmico e científico. Ela fez com que eles saíssem do lugar de objetos de pesquisa e os legitimou como sujeitos que são.

Contar a história da Just Crew nesse artigo já fez a diferença nas nossas vidas e na nossa cidade, mas fez também a diferença na universidade. Juntos, nós reinventamos a experiência da etnografia, da pesquisa e do compartilhamento de informações e conhecimento. Mesmo antes que esse texto seja publicado, esses encontros e trocas contribuíram para que os skatistas nevenses percebessem que, apesar da legitimação oficial da universidade (um espaço que, até então, só produzia exclusão e exploração dos saberes) eles não precisam de validação de nenhuma instituição oficial 


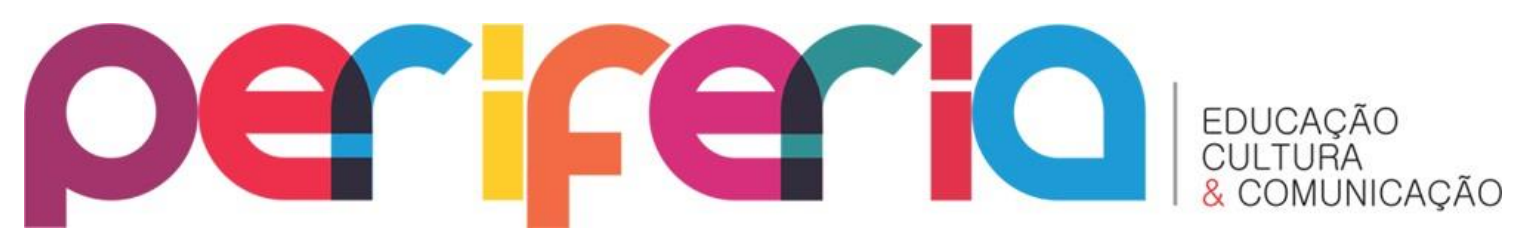

ISSN:1984-9540

DOI: $10.12957 /$ periferia.2020.49114 para existirem. As vozes que produzem essas narrativas oficiais negativas e de ódio não são vozes das quais queremos ou esperamos qualquer tipo de legitimação, porque quem mais queremos que ouçam outras histórias, que contem outras histórias, são o próprio povo nevense e a população negra, são as pessoas que estão em locais de disputa parecida com o nosso. São essas vozes, essas imagens, essas trajetórias, essas histórias que importam agora, porque é extremamente relevante que possamos nos ver, nos ouvir, nos conhecer, nos divulgar. Porque é muito importante que não tenhamos uma história única com a qual nos identificar.

Nesses dois anos em que a CAPES financiou a minha pesquisa, e me ajudou a custear as despesas básicas de sobrevivência, a Just Crew somou forças com outros coletivos nevenses e ocupou uma escola municipal abandonada pelo poder público em Ribeirão das Neves. O espaço chamado Curumim, com salas de aulas, quadra esportiva, banheiros e pátio, hoje é a casa de vários grupos que oferecem oficinas gratuitas para crianças, jovens, adultos e idosos moradores da região de Justinópolis. Ali funciona o Centro de Treinamento Avançado para os skatistas que já tem mais experiência na Just Crew, e também as oficinas de skate para iniciantes; atividades de empreendedorismo social; festivais, entre outros. 0 espaço recebe manutenção, limpeza e é gerido pelos próprios jovens e moradores do entorno, que cuidam para que a escola abandonada ainda cumpra sua função educativa. Eles são educadores uns dos outros. Eles estão dando ollies e mais ollies nas barreiras em busca de justiça social e transformando a realidade.

Além disso, a Just Crew também enviou representantes do grupo (Davidson, Jhonatan e Vilson) para participarem comigo do XI Seminário Vozes das Periferias realizado em novembro de 2019 na FEBF - Duque de Caxias. Eles não só dividiram sua história com outros pesquisadores do programa de PósGraduação, como também realizaram um sonho: andar de skate na Praça XV, pólo de encontro dos skatistas no centro do Rio de Janeiro. Sem contar na alegria do Vilson, que entrou pela primeira vez no mar. Memórias de outras histórias que não serão esquecidas e que, com certeza, apresentam 


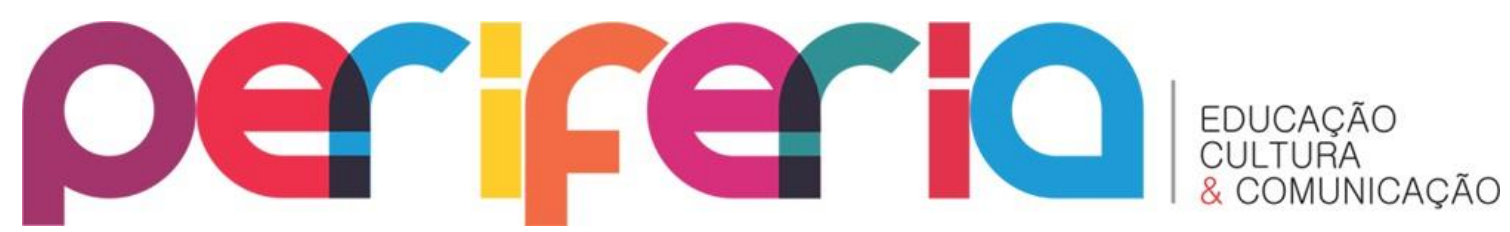

ISSN:1984-9540

DOI: $10.12957 /$ periferia.2020.49114 repertórios de muito mais amor, amizade, liberdade e vida para se identificar. Aliás, escutei do Jhonatan outra pergunta que me fez acreditar que o propósito da minha vinda para a UERJ não foi mesmo em vão. "Rafa, como é mesmo o nome desse trem que você faz aqui?". "Mestrado.". "Vou fazer também".

Ele pode mudar de ideia quanto a isso, mas só de ouvi-lo colocando a pós-graduação como uma das muitas possibilidades de escolha profissional que tem, já é outro ollie nas narrativas dominantes. Concorda? A narrativa da "história única" sobre a cidade de Ribeirão das Neves não é única e vem sendo contestada pelos jovens da Just Crew Skateboard todos os dias. Mesmo estando em uma cidade atada a um discurso desencorajador de enclausuramento e medo, eles ousam questionar o estereótipo nevense dando ollies com seus skates, nas alturas e em liberdade.

\section{REFERÊNCIAS}

ABEP, Associação Brasileira de Empresas de Pesquisa. Critério de classificação econômica Brasil 2016. Disponível em http://www.abep.org/codigos-e-guiasda-abep, acesso em 14 de novembro de 2018.

ADERALDO, Guilhermo André. Reinventando a cidade: disputas simbólicas em torno da produção e exibição audiovisual de coletivos culturais em São Paulo. 2013. Tese de Doutorado. Universidade de São Paulo.

ADICHIE, Chimamanda. O perigo de uma única história.Tradução de Eri a Barbosa. Original disponível em: http://www. ted. com/tal s/lang/pt$\mathrm{br} / \mathrm{chimamanda}$ adichie_the_danger_of_a_single_story. html. s/d. Tradução disponível em: http://www. google. pt/url, 2009.

BITTENCOURT, Luciana. A fotografia como instrumento etnográfico. Anuário antropológico, v. 17, n. 1, p. 225-241, 1994.

CAIAFA, Janice. Aventura das cidades: ensaios e etnolografias. FGV Editora, 2007.

CBSK, Confederação Brasileira de Skate. Pesquisa Datafolha 2015. Disponível em:

Periferia, v. 12, n. 3, p. 322-346, set./dez. 2020 


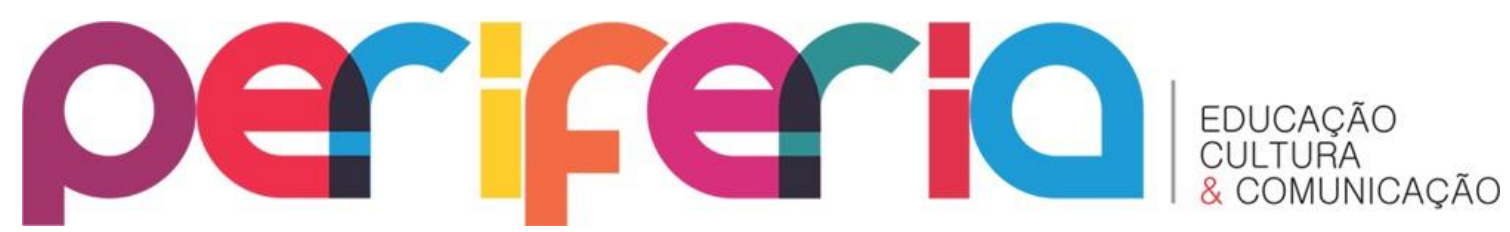

ISSN:1984-9540

DOI: $10.12957 /$ periferia.2020.49114

http://www.umti.com.br:8040/uploads/ckeditor/attachments/4449/Pesquisa Datafolha_2015.pdf, acesso em 14 de novembro de 2011.

IBGE. Censo 2010 - Ribeirão das Neves. Disponível em:

http://www.censo2010.ibge.gov.br, acesso em 30 de maio de 2018.

HIKIJI, Rose Satiko G. Imagens que afetam: filmes da quebrada e o filme da antropóloga. Devires imagéticos: a etnografia, o outro e suas imagens. Rio de Janeiro, v. 7, p. 115-135, 2003.

MACHADO, Giancarlo Marques Carraro. De carrinho pela cidade: a prática do street skate em São Paulo. 2011. Tese de Doutorado. Universidade de São Paulo.

MAGNANI, José Guilherme Cantor. De perto e de dentro: notas para uma etnografia urbana. Revista brasileira de ciências sociais, v. 17, n. 49, p. 1129, 2002.

NOVAES, Sylvia Caiuby. Imagem, magia e imaginação: desafios ao texto antropológico. Mana, v. 14, n. 2, p. 455-475, 2008.

ZALUAR, Alba. O contexto social e institucional da violência. Núcleo de Pesquisa das Violências-NUPEVI do Instituto de Medicina Social da UERJ, 2003. 